Chirurgia (2018) 113: 244-252

No. 2, March - April

Copyright@ Celsius

http://dx.doi.org/10.21614/chirurgia.113.2.244

\title{
The Revisited Role of Ultrasound Guided Core Needle Biopsy in the Breast Cancer Diagnosis
}

\author{
Flavius Mocian', Rareș Georgescu', Marius Florin Coroș', Ioana Colcer', Bauer Orsolya Hanko', \\ Adela-Luciana Oprea', Simona Stolnicu
}

'Department of Surgery I, University of Medicine and Pharmacy of Târgu Mureș, Mureș

2Department of Pathology, University of Medicine and Pharmacy of Târgu Mureș, Mureș

Corresponding author:

Rareș Georgescu, MD

Clinic of Surgery I, Mureș County

Hospital, University of Medicine

and Pharmacy of Târgu Mureș

E-mail: rares1geo@gmail.com

\author{
Abbreviations: \\ ADH - Atypical Duct Hyperplasia; \\ CNB - Core Needle Biopsy; \\ DCIS - Ductal Carcinoma In Situ; \\ LCIS - Lobular Carcinoma In Situ; \\ LN - Lobular Neoplasia; \\ MRI - Magnetic Resonance; \\ $\mathrm{NL}$ - Lobular Neoplasia; \\ NST - No Special Type; \\ ROC - Receiver Operating Characteristic;
}

Received: 14.12 .2017

Accepted: 20.01.2018

\section{Rezumat}

Reevaluarea rolului biopsiei cu ac gros ghidată ecografic în diagnosticul cancerului mamar

Introducere: Biopsia cu ac gros (BAG) reprezintă o alternativă labiopsia chirurgicală în stabilirea diagnosticului histopatologic al leziunilor mamare.

Scopul studiului: Scopul studiului este de a determina acuratețea BAG ghidată ecografic în stabilirea diagnosticului de cancer mamar.

Material şi metodă: Am analizat retrospectiv, datele pacientelor diagnosticate cu leziuni mamare prin BAG ghidată ecografic în perioada Mai 2012 - Decembrie 2014. 163 de biopsii au fost efectuate la 155 de paciente. Pentru a evalua acuratețea diagnosticului BAG ghidată ecografic, rezultatele au fost corelate cu standardul de referință reprezentat de către evaluarea exciziei chirurgicale a leziunii mamare, astfel că 90 de paciente (94 leziuni mamare) au fost incluse în lotul de studiu. Am calculat concordanța rezultatelor, folosind Coeficientul Kappa, sensibilitatea şi specificitatea folosind Curba ROC şi rata fals-negativă.

Rezultate: BAG ghidată ecografic a identificat 74 (79\%) leziuni maligne, 1 (1\%) leziune precursoare cu risc înalt de malignitate şi 19 (20\%) leziuni benigne. Concordanța între rezultatele histopatologice a fost $96.8 \%$ (kappa: 0.91). Concordanța tipului histologic a putut fi calculată în cazul a 70 de carcinoame invazive şi a fost de $94.2 \%$ (kappa: 0,80). Concordanța gradului histologic a putut fi calculată în cazul a 55 de carcinoame invazive şi a fost de $61,8 \%$ (kappa: 0,41). 
Sensibilitatea şi specificitatea au fost de $98.6 \%$ respectiv $100 \%$. Rata fals negativă a fost $1.3 \%$. Concluzii: BAG ghidată ecografic este o alternativă excelentă a biopsiei chirurgicale în stabilirea diagnosticului histopatologic al leziunilor mamare, cu condiția ca aceasta să fie efectuată de o echipă specializată şi să existe o concordanță clinico-radiologico-histopatologică în toate cazurile.

Cuvinte cheie: biopsia cu ac gros ghidată ecografic, sensibilitate, specificitate, cancer mamar

\section{Abstract}

Background: Core needle biopsy (CNB) is an alternative to surgical biopsy in establishing the histopathological diagnosis of mammary lesions.

Aim of the study: The aim is to determine the accuracy of ultrasound guided CNB (US-CNB) in establishing breast cancer diagnosis.

Materials and methods: We retrospectively analyzed the data of US-CNB patients between May 2012 - December 2014. One hundred sixty-three biopsies were performed in 155 patients. To assess the diagnostic accuracy of US-CNB, the results were correlated with the gold-standard of surgical excision of the breast lesions, thus, 90 patients (94 breast lesions) were included in the study group. We calculated the concordance of the results using the Kappa Coefficient, sensitivity and specificity using the ROC curve and the false-negative rate.

Results: US-CNB identified 74 (79\%) malignant lesions, 1 (1\%) precursor high-risk lesion, and 19 (20\%) benign lesions. Concordance between histopathological results was 96.8\% (kappa: 0.91). The 94.2\% (kappa: 0.80) consensus of the histological type could be calculated for 70 invasive carcinomas. The 61.8\% (kappa: 0.41) concordance of the histological grade could be calculated for 55 invasive carcinomas. Sensitivity and specificity were $98.6 \%$, and $100 \%$, respectively. The false-negative rate was $1.3 \%$.

Conclusions: US-CNB is an excellent alternative to surgical biopsy in establishing the histopathological diagnosis of breast lesions, provided it is performed by a specialized team and there is clinical-radiological-histopathological concordance in all cases.

Key words: ultrasound guided core needle biopsy, sensibility, specificity, breast cancer

\section{Introduction}

Breast biopsy has emerged from the need to establish whether a lesion is benign or the malignant. Prior to the beginning of the $20^{\text {th }}$ century, breast cancer was diagnosed in advanced stages by clinical examination only when the tumor was accessible to palpation. With the development of imaging methods used in breast pathology (mammography and ultrasound), both benign and especially malignant lesions could be diagnosed from the early stages, so breast cancer prognosis was improved (1).

Currently, patients with breast pathology are examined using the so-called "triple assessment" process which consists of correlating the results of the clinical, imaging, and histopathological examinations. This triple assessment is performed in order to increase the accuracy of breast lesion diagnosis (2).

CNB with high diagnostic accuracy are firstly used for the histopathological assessment of breast lesions, thus leading to a decline in the use of surgical biopsies. Being a percutaneous method, it is much less invasive than surgical biopsy, it can be performed quickly, it is cheaper, does not deform the breast and does not cause visible scars. Complications such as hematomas or infections may occur in less than 
one case in 1,000 patients (3). To increase the accuracy of the diagnosis, CNB can be imagistically guided either by stereotaxic method or most commonly by ultrasound, and, more recently, by nuclear magnetic resonance (MRI) $(3,4)$.

The goal to be met by CNB is that the method should have the highest possible sensitivity and specificity, and, at the same time, it should provide as much information as possible about the tumor such as the benign or malignant character of the lesion, and additionally, in the case of malignant tumors, the histological type and grade, as well as the molecular profile (4). According to the literature, the sensitivity of the method varies between $85-100 \%$, while specificity varies between $86-100 \%$ (5).

The histological type of the tumor has been shown to be a prognostic factor in breast cancer. In the vast majority of cases, the histological type can be identified on the tissue obtained by $\mathrm{CNB}$, the concordance between its result and the result of surgical excision of the entire lesion, being between $93-100 \%$. The histological grade of the tumor is also known to be a prognostic factor in breast cancer, but also predictive in the response to treatment, playing a vital role in establishing the treatment, the concordance between the result of CNB and that of the surgical excision can be determined in approximately $75 \%$ of cases and ranges from 59 to $91 \%$ (6).

The purpose of this paper is to determine the accuracy with which ultrasound guided CNB (US-CNB) can establish breast cancer diagnosis in the experience of our multidisciplinary team, in terms of consistency with histopathological results of surgical excision (gold-standard), as well as sensitivity and specificity of the method and, last but not least, the false-negative rate. All these data are of great importance both in the correct treatment of patients with breast carcinoma and in the continuous improvement of the multidisciplinary team.

\section{Materials and Methods}

Our 3-year retrospective study analyzed clini- cal, imaging and morphologic data in patients who had undergone US-CNB in the Clinic of Surgery I, Mureş County Hospital and the Puls Medical Center in Târgu Mureş during May 2012 - December 2014. During the study, 163 biopsies were performed in 155 patients with breast suspicious lesions. The data were extracted by consulting the histopathological records of these 155 patients in the Department of Pathology of the Mureş County Emergency Hospital.

In our study, the gold standard was represented by the histopathological result of surgical excision of the breast lesion. Thus, we excluded 65 patients (69 breast lesions) that were not subjected to surgical excision after the biopsy, and for whom the result of the biopsy did not automatically have a reference standard. Also, we excluded patients who had undergone surgical excision but who received neoadjuvant oncology therapy during the time of the biopsy and that of the excision. Thus, a total of 90 patients (94 beast lesions) who had been subjected to biopsy and who, after a certain period of time (on average 3 weeks), had also been subjected to surgical excision of the lesion were included in the study group.

All biopsies were performed using an automatic biopsy instrument (Bard-Magnum Biopsy Instrument, Covington, GA, USA) and 14, 16, and $18 \mathrm{G}$ Tru-Cut biopsy needles. Ultrasound was used as an imaging guide method. Each biopsy was performed with the patient in a supine position and the ipsilateral upper limb raised above the head. Prior to the puncture, local anesthesia was used. The lesion was localized by ultrasound, and a spot incision was made at the puncture site to facilitate the penetration of the biopsy needle. The biopsy needle, when passing through the lesion, and during its entire trajectory was permanently visualized on ultrasound. The biopsy material was immediately fixed in formalin for 2448 hours and sent for histopathological examination.

All biopsies were performed by the same surgeon (RG) and all biopsy materials were examined by the same pathologist (SS).

Histopathological results were classified into 
malignant (infiltrating and in situ carcinoma), high-risk precursor lesions (e.g. atypical duct hyperplasia - $\mathrm{ADH}$, lobular neoplasia - NL) and benign $(7,8,9)$. Microscopic classification was performed according to the 2012 WHO classification (10). Microscopic grading was made according to the modified Elston-Ellis method (11).

We calculated the concordance between US-CNB and gold-standard results using the Kappa Coefficient and a 95\% confidence interval. The reference values of the Kappa Coefficient are presented in Table 1. In invasive carcinomas we also calculated the histological type and grade of the lesion.

US-CNB sensitivity and specificity were calculated using the Receiver Operating Characteristic (ROC) curve, with the histopathological result of the surgical excision as the reference standard.

The false-negative rate was defined as the ratio of breast cancer (invasive or in situ) with a benign diagnosis on US-CNB (9).

For statistical calculations we used MedCalc ver. 15.2.1 (MedCalc Software www.medcalc.org).

\section{Results}

The histopathological results of US-CNB are listed in Table 2. Of the 94 lesions, 74 (79\%) were malignant (70 invasive, 4 in situ), 1 (1\%) was a precursor lesion and $19(20 \%)$ were benign.

The concordance between histopathological results of US-CNB and those of surgical excision (Table 3) was 96.8\% (91/94) with a
Table 1. Kappa coefficient values

\begin{tabular}{ll}
\hline Kappa & Concordance \\
\hline$<0,20$ & very low \\
\hline $0,21-0,40$ & low \\
\hline $0,41-0,60$ & moderate \\
\hline $0,61-0,80$ & good \\
\hline $0,81-1,00$ & very good \\
\hline
\end{tabular}

Table 2. Histopathological distribution of lesions assessed by US-CNB

\begin{tabular}{lc}
\hline Findings & No. of lesions \\
\hline Benign & $n=19$ \\
Fibroadenoma & 9 \\
Benign phylloides tumor & 2 \\
Fibrocystic disease & 2 \\
Sclerosing papilloma & 1 \\
Others & 5 \\
\hline Precursor lesion & $n=1$ \\
\hline Atypical ductal hyperplasia (ADH) & 1 \\
\hline Malignant & $n=74$ \\
\hline In situ carcinoma & \\
\hline Ductal carcinoma in situ (DCIS) & 2 \\
Papillary carcinoma in situ & 2 \\
\hline Invasive carcinoma & \\
\hline Invasive NST carcinoma & 59 \\
Invasive lobular carcinoma & 4 \\
Others & 7 \\
\hline
\end{tabular}

kappa value of 0.91 (95\% confidence interval: between 0.82 and 0.99 ).

The concordance of the histological type could be calculated for 70 invasive carcinomas (Table 4), it was $94.2 \%(66 / 70)$ with a kappa value of 0.80 (95\% confidence interval: between 0.62 and 0.99 ).

The concordance of the histological grade

Table 3. Concordance between the results of US-CNB and those of surgical excision

\begin{tabular}{|c|c|c|c|c|c|c|}
\hline & & \multirow[b]{2}{*}{$\begin{array}{l}\text { Benign } \\
\text { lesion }\end{array}$} & \multicolumn{4}{|c|}{ Surgical excision } \\
\hline & & & $\begin{array}{l}\text { Precursor } \\
\text { lesion }\end{array}$ & $\begin{array}{c}\text { In situ } \\
\text { carcinoma }\end{array}$ & $\begin{array}{l}\text { Invasive } \\
\text { carcinoma }\end{array}$ & Total \\
\hline \multirow[t]{5}{*}{ US-CNB } & Benign lesion & 18 & 0 & 0 & 1 & 19 \\
\hline & Precursor lesion & 0 & 1 & 0 & 0 & 1 \\
\hline & In situ carcinoma & 0 & 0 & 2 & 2 & 4 \\
\hline & Invasive carcinoma & 0 & 0 & 0 & 70 & 70 \\
\hline & Total & 18 & 1 & 2 & 73 & 94 \\
\hline
\end{tabular}


Table 4. Concordance of the histological type in the case of invasive breast carcinomas

\begin{tabular}{llcccc}
\hline & & & & Surgical excision \\
\hline & & Another histological type & Lobular & Ductal & Total \\
US-CNB & Another histological type & 6 & 0 & 1 & 7 \\
& Lobular & & & \\
\hline 0 & 4 & 0 & 4 \\
\hline Ductal & & & \\
\hline 2 & 8 & 5 & 5 & 59 \\
\hline Total & & & 70 \\
\hline
\end{tabular}

Table 5. Concordance of the histological grade in the case of invasive breast carcinomas

\begin{tabular}{cccccc}
\hline & & \multicolumn{4}{c}{ Surgical excision } \\
\hline & & Grade 1 & Grade 2 & Grade 3 & Total \\
US-CNB & Grade 1 & 16 & 7 & 4 & 27 \\
& Grade 2 & 3 & 13 & 7 & 2 \\
& Grade 3 & 0 & 0 & 5 & 5 \\
\hdashline Total & 19 & 20 & 16 & 55 \\
\hline
\end{tabular}

could be calculated for 55 invasive carcinomas (Table 5). It was $61.8 \%(34 / 55)$ with a kappa value of $0.41(95 \%$ confidence interval: between 0.22 and 0.59 ).

Values obtained for sensitivity and specificity were calculated using the ROC Curve (Fig. 1) and were $98.6 \%$ and $100 \%$, respectively.

The false-negative rate, according to definition, was $1.3 \%$ (1 false-negative result).

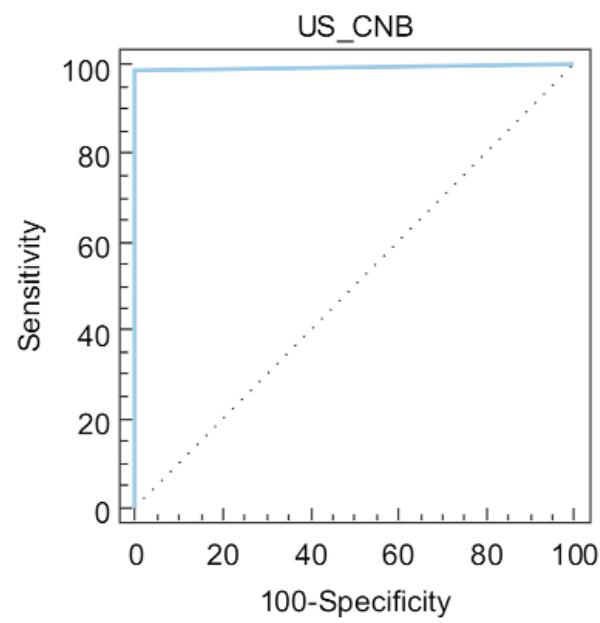

Figure 1. ROC curve

\section{Discussions}

The results of our study show that there is a $96.8 \%$ concordance between histopathological results of US-CNB and those of surgical excision. The kappa coefficient of 0.91 indi- $^{-}$ cates a very high correlation of histopathological results which means that results could be correlated in the case of 91 lesions of the total of 94 included in the study group.

These values are close to those published in the literature. Schueller et al (7) report a $94.6 \%$ concordance of the results and a kappa coefficient of 0.89 . In another study, published by Wiratkapun et al (8), the concordance of the results is $92 \%$ and the value of the kappa coefficient is 0.86 .

Additional information on malignant tumors, referring to the histological type and grade, can be highlighted by US-CNB. These prognostic factors, as they are called in the literature, play a fundamental role in the therapeutic strategy of patients diagnosed with breast cancer (6).

We were able to calculate the histological type of 70 invasive carcinomas. This was $94.2 \%$ with a kappa coefficient of 0.80 , values which indicate a high degree of correlation. 
Of the 70 invasive carcinomas, $66(94.2 \%)$ had the same histological type [56 (84.8\%) no special type - NST invasive carcinomas, 4 (6.06\%) invasive lobular carcinomas, 6 (9.09\%) invasive carcinomas with a different histological type] both in US-CNB histopathological results and those of surgical excision. In the case of 4 (5.71\%) invasive carcinomas, histological type results were discontinuous. Of these, an invasive NST carcinoma identified by US-CNB proved to be in fact an invasive lobular carcinoma in surgical excision. Two invasive NST carcinomas were identified by surgical excision as invasive carcinomas of another histological type. An invasive carcinoma with a different histological type identified by US-CNB proved to be NST invasive carcinoma on surgical excision. Inconsistency in the four cases can be explained by the lack of specific markers (e.g. ECadherin) which are very useful in differentiating between NST infiltrating carcinoma and infiltrative lobular carcinoma but which the pathology laboratory sometimes lacks. On the other hand, the inconsistency about the microscopic type may also occur due to the heterogeneity of the tumors. On biopsy, the biopsy material obtained may sometimes not be representative of the whole tumor (6).

As far as the concordance of the histological grade is concerned, we could calculate it for 55 invasive carcinomas. It was $61.8 \%$ with a kappa coefficient of 0.41 . These values indicate a moderate degree of correlation.

Thirty-four (61.8\%) invasive carcinomas of a total of 55 had the same histological grade on both US-CNB and surgical excision. Of these, $16(47.1 \%)$ invasive carcinomas were grade $1,13(38.2 \%)$ invasive carcinomas were grade 2 and 5 (14.7\%) invasive carcinomas were grade 3 . Discontinuous results in terms of histological grade were found in 21 (38.1\%) cases of invasive carcinomas. Among grade 1 carcinomas identified by US-CNB, 7 (33.3\%) carcinomas were grade 2 and 4 (19.1\%) carcinomas were grade 3 on surgical excision. In the case of grade 2carcinomas, $3(14.2 \%)$ carcinomas were grade 1 and $7(33.3 \%)$ were grade 3 carcinomas on surgical excision. There were no discontinuous results in the case of grade 3 carcinomas. These inconsistencies regarding the histological grade can be explained by the difficult interpretation of the three parameters which are evaluated in order to establish the microscopic grade of a lesion (lumen formation, but especially nuclear polymorphism and number of mitoses) in the case of small biopsy tissue fragments, with extensive necrosis, and especially tracing artifacts when biopsy is performed. Therefore, in these cases the pathologist recommends the re-evaluation of the microscopic grade of the tumor on surgical specimen.

Table 6 presents the results of our study regarding the consistency of histological type and grade of breast carcinomas compared to other studies that investigated the same problem.

Following the analysis of the results, it can be stated that US-CNB can identify the histological type of breast carcinomas in the vast majority of cases. Concerning the consistency of the histological grade, we can state that US-CNB correctly identified the grade of breast carcinomas in over half of the cases. It should be stressed that in the case of grade 3 carcinomas there were no inconsistent results,

Table 6. Values of similar studies regarding the concordance between histological type and grade

\begin{tabular}{|c|c|c|c|c|}
\hline & \multicolumn{2}{|c|}{ Histological type } & \multicolumn{2}{|c|}{ Histological grade } \\
\hline & $\%$ & kappa & $\%$ & kappa \\
\hline Deshpande et al (16) & - & 0.63 & - & 0.58 \\
\hline Usamiet al (17) & - & - & 75 & 0.55 \\
\hline Tamaki et al (18) & 84.4 & 0.70 & 81.3 & 0.64 \\
\hline Oughet al (19) & - & - & 63 & 0.43 \\
\hline Our study & 94.2 & 0.80 & 61.8 & 0.41 \\
\hline
\end{tabular}


so we can say that the highest concordance could be reached for these carcinomas.

In order to synthesize what has been said so far, it is very important that a diagnostic method, US-CNB in our case, apart from identifying the malignant character of a breast lesion, should also provide additional information about tumor histology, namely, the histological type and grade. The study on the concordance of the molecular profile (another prognostic and predictive factor) is currently being conducted and will be published in a subsequent article by the same team.

Using the ROC curve, we calculated the sensitivity and specificity of US-CNB. The sensitivity value was $98.6 \%$, while specificity was $100 \%$. These values fall within the ranges published in the literature, namely $85-100 \%$ for sensitivity and $86-100 \%$ for specificity (5). Table 7 presents the results of our study regarding the sensitivity and specificity of the method compared to the results of other studies that address the same subject.

Based on the results of our study regarding sensitivity and specificity, we can state that US-CNB is the method of choice when the aim is to find the histopathological diagnosis of a breast lesion. At the same time, US-CNB is an alternative to surgical biopsy.

The probable main limitation of US-CNB is the occurrence of false-negative results. A false-negative result is defined as a benign lesion that is identified by US-CNB, but which later, on surgical excision, proves to be a breast cancer.

Our study recorded only one false-negative result, with a false-negative rate of $1.3 \%$. Schueller et al (7) report a false-negative rate of $1.6 \%$; while in the study of Wiratkapun et al (8) the false-negative rate is $4 \%$.
In the case of the false-negative result found in our study, imaging revealed a suspicious malignant lesion. Following US-CNB, the histopathological result was sclerosing papilloma. In this situation of inconsistency between radiological examination and the histopathological diagnosis on US-CNB, the multidisciplinary team will decide whether to perform a second biopsy or a surgical excision. In our case, the multidisciplinary team agreed to perform a surgical excision of the lesion. The final histopathological result on the surgical specimen was of invasive carcinoma of NST type.

Factors that may lead to false-negative results may be: poor visualization of the lesion or that of the biopsy needle, mobility of the lesion, lesion localization (in the case of lesions near the thoracic wall), bulky breast lesions, breasts with fibrous tissue but also lesions difficult to interpret microscopically on a biopsy fragment such as papillary lesions, sclerosing lesions, fibroid tumors, atypical ductal hyperplasia versus in situ ductal carcinoma, invasive carcinomas with a sclerotic abundant stroma and insufficient tumor tissue (previously called scirrhous carcinomas). All of these factors may cause technical errors at the time of biopsy, inevitably leading to false-negative results $(7,12)$

False-negative results can lead to a delay in the diagnosis of breast cancer and the correct decision of a therapeutic strategy (9). It is therefore essential to correlate the imaging results with the histopathological ones in order to reduce, as far as possible, the falsenegative rate (12).

It is noteworthy that no false-positive results were recorded by in our study.

Another disadvantage of US-CNB is the

Table 7. Results of similar studies on sensitivity and specificity

\begin{tabular}{lcccc}
\hline Study & Year & No. of lesions & Sensibility (\%) & Specificity (\%) \\
\hline Bolivar et al (20) & 2005 & 204 & 97 & 100 \\
\hline Lacambra et al (21) & 2012 & 285 & 96 & 99 \\
\hline Moschetta et al (12) & 2014 & 154 & 97 & 96 \\
\hline Our study & 2015 & 94 & 98.6 & 100 \\
\hline
\end{tabular}


emergence of underestimated results. Histological underestimation occurs when the US-CNB result reveals a high-risk precursor lesion (e.g. ADH) or a DCIS (ductal carcinoma in situ) while the remaining un-biopsied lesion contains in situ (or invasive) breast cancer (8). We encountered 2 underestimated results in our study. US-CNB identified DCIS in both cases, whereas the result of surgical excision was invasive NST carcinoma. One reason for this incongruity can be either the biopsy of only the invasive lesion periphery (which exhibits areas of DCIS, in some cases of extensive type, i.e. with many DCSI foci), whereas only the center of the lesion has obvious invasive area which was missed at the time of biopsy.

Our study recorded only one high-risk precursor lesion identified by US-CNB, namely atypical ductal hyperplasia $(\mathrm{ADH}) . \mathrm{ADH}$ is defined as a lesion that has some, but not all, histopathological characteristics of a ductal carcinoma in situ (DCIS). It is limited to less than 2 ducts and/ or has a total diameter of less than $2 \mathrm{~mm}(13,14)$. After performing surgical excision in this lesion, histopathology revealed a high grade lobular neoplasia - lobular carcinoma in situ (LCIS), which is also considered to be a high-risk precursor lesion and a non-obligatory precursor to develop breast cancer in the future $(7,8,9,15)$. In cases in which the biopsy identifies $\mathrm{ADH}$ or lobular neoplasia (LN) foci, it is indicated that the term DCIS should not be used because the lesion extension cannot always be established, this being an essential parameter for differentiation between $\mathrm{ADH}$ and DCIS. On the other hand, in the case of LN, it is not always possible to establish the histological grade of the biopsy for the same reason. Rarely, differentiation between ADH/ DCIS and LN on biopsy cannot accurately be made, as in the present case even with the help of ancillary studies.

Certainly, our study has some limitations. The first is the small number of cases compared to other studies that address the same subject. The second would be the few cases of DCIS $(\mathrm{n}=2)$ and $\mathrm{ADH}(\mathrm{n}=1)$, thus no statistical determination of the underestimation rate is possible.

\section{Conclusion}

In conclusion, the results of our study argue that US-CNB is the method of choice and at the same time an alternative to surgical biopsy in establishing the histopathological diagnosis of breast lesions.

US-CNB offers many advantages: it is a safe, fast, cheap method, it does not use ionizing radiation, and it allows the real-time visualization of the biopsy needle. Also, being a minimally invasive method, it offers the patient a high level of comfort.

In addition to the fact that US-CNB can diagnose breast cancer with high accuracy, it can also provide additional information about the tumor, referring here to prognostic and predictive factors. These, particularly the histological type and grade of the tumor and the molecular profile, play an essential role in the therapeutic strategy of patients diagnosed with breast cancer.

The main and most feared limitation of US-CNB is the appearance of false-positive or false-negative results. The later leads to a delay in diagnosing breast cancer. Therefore, in order to reduce the false-negative rate as far as possible, it is essential to correlate the imaging results with the histopathological ones.

In conclusion, we would like to emphasize the fact that the role of the multidisciplinary team in making decisions on the therapeutic strategy of patients diagnosed with breast cancer is essential, referring here to the surgeon, the pathologist and radiologist.

\section{Authors' Contributions}

Flavius Mocian - data collection and statistics. Rares Georgescu - study design, patient enrollement. Marius Florin Coros - article review. Ioana Colcer - data collection, bibliography collection. Bauer Orsolya Hanko statistics, literature review. Adela-Luciana Oprea - literature review. Simona Stolnicu study design, article review.

\section{Conflict of Interests}

The authors declare no conflict of interests. 


\section{Acknowledgments}

We thank to Adrian Naznean from to Foreign Language Department, University of Medicine and Pharmacy of Tirgu Mures for carefully translating and editing the manuscript.

\section{References}

1. Michell M. A history of breast diagnosis. In: Drew P, Cawthorn S, Michell M. Interventional ultrasound of the breast. Informa Healthcare. London; 2007. p1-9.

2. O'Flynn EAM, Wilson ARM, Michell MJ. Image-guided breast biopsy: state-of-the-art. Clin Radiol. 2010;65(4):259-70. doi: 10.1016/j.crad. 2010.01.008.

3. Liberman L. Centennial dissertation. Percutaneous imaging-guided core breast biopsy: state of the art at the millennium. AJR Am J Roentgenol. 2000; 174(5):1191-9.

4. Apesteguía L, Pina LJ. Ultrasound-guided core-needle biopsy of breast lesions. Insights Imaging. 2011 Aug;2(4):493-500. Epub 2011 Apr 15.

5. Willems SM, van Deurzen CHM, van Diest PJ. Diagnosis of breast lesions: fine-needle aspiration cytology or core needle biopsy? A review. J Clin Pathol. 2012;65(4):287-92. doi: 10.1136/jclinpath2011-200410. Epub 2011 0ct 29.

6. Rakha EA, Ellis IO. An overview of assessment of prognostic and predictive factors in breast cancer needle core biopsy specimens. J Clin Pathol. 2007;60(12):1300-6. Epub 2007 Jul 14.

7. Schueller G, Jaromi S, Ponhold L, Fuchsjaeger M, Memarsadeghi M, Rudas M et al. US-guided 14-gauge core-needle breast biopsy: results of a validation study in 1352 cases. Radiology. 2008; 248(2):406-13. doi: 10.1148/radiol.2482071994.

8. Wiratkapun C, Treesit T, Wibulpolprasert B, Lertsithichai $P$. Diagnostic accuracy of ultrasonography-guided core needle biopsy for breast lesions. Singapore Med J. 2012;53(1):40-5.

9. Youk JH, Kim EK, Kim MJ, Oh KK. Sonographically guided 14gauge core needle biopsy of breast masses: a review of 2.420 cases with long-term follow-up. AJR Am J Roentgenol. 2008; 190(1):202-7
10. Lakhani S, Ellis IO, Schnitt SJ, Tan PH, van de Vijver MJ. World Health Organization classification of tumors of the breast. Lyon: IARC Press; 2012. p. 13-77.

11. Ellis IO, Elston CW. Histologic grade. In: O'Malley FP, Pinder SE, editors. Breast pathology. Philadelphia, PA: Elsevier; 2006. p. 225-33.

12. Moschetta M, Telegrafo M, Carluccio DA, Jablonska JP, Rella L, Serio $\mathrm{G}$ et al. Comparison between fine needle aspiration cytology (FNAC) and core needle biopsy (CNB) in the diagnosis of breast lesions. G Chir. 2014;35(7-8):171-6.

13. Neal L, Sandhu NP, Hieken TJ, Glazebrook KN, Mac Bride MB, Dilaveri CA et al. Diagnosis and management of benign, atypical, and indeterminate breast lesions detected on core needle biopsy. Mayo Clin Proc. 2014;89(4):536-47. doi: 10.1016/j.mayocp. 2014.02.004.

14. Masood S, Rosa M. Borderline breast lesions: diagnostic challenges and clinical implications. Adv Anat Pathol. 2011 ;18(3):190-8. doi: 10.1097/PAP.0b013e31821698cc.

15. O'Malley FP. Lobular neoplasia: morphology, biological potential and management in core biopsies. Mod Pathol. 2010;23 Suppl 2:S14-25. doi: 10.1038/modpathol.2010.35.

16. Deshpande A, Garud T, Holt SD. Core biopsy as a tool in planning the management of invasive breast cancer. World J Surg Oncol. 2005;3(1):1.

17. Usami S, Moriya T, Amari M, Suzuki A, Ishida $\mathrm{T}$, Sasano $\mathrm{H}$ et al. Reliability of prognostic factors in breast carcinoma determined by core needle biopsy. Jpn J Clin Oncol. 2007;37(4):250-5. Epub 2007 May 7.

18. Tamaki K, Sasano H, Ishida T, Miyashita M, Takeda M, Amari M et al. Comparison of core needle biopsy (CNB) and surgical specimens for accurate preoperative evaluation of ER, PgR and HER2 status of breast cancer patients. Cancer Sci. 2010; 101(9):2074-9. doi: 10.1111/j.1349-7006.2010.01630.x.

19. Ough M, Velasco J, Hieken TJ. A comparative analysis of core needle biopsy and final excision for breast cancer: histology and marker expression. Am J Surg. 2011;201(5):692-4. doi: 10.1016/.amjsurg.2010.02.015. Epub 2010 Sep 18.

20. Bolívar AV, Alonso-Bartolomé P, García EO, Ayensa FG. Ultrasoundguided core needle biopsy of non-palpable breast lesions: a prospective analysis in 204 cases. Acta Radiol. 2005;46(7):690-5

21. Lacambra MD, Lam CC, Mendoza P, Chan SK, Yu AM, Tsang JY et al. Biopsy sampling of breast lesions: comparison of core needle- and vacuum-assisted breast biopsies. Breast Cancer Res Treat. 2012; 132(3):917-23. doi: 10.1007/s10549-011-1639-3. Epub 2011 Jun 23. 